\title{
The Lived Experiences of the Partners of Breast Cancer Survivors: Psychosocial Difficulties and Changes
}

\author{
Figen Şengün İnan ${ }^{1}$ (iD, Neslihan Partlak Günüşen ${ }^{1}$ (iD, Murat Keser $^{2}$ (iD , \\ İlhan Öztop ${ }^{3}$ (D)
}

'Dokuz Eylül University Faculty of Nursing, Department of Psychiatric Nursing, Izmir, Turkey

${ }^{2}$ Tepecik Training and Research Hospital, Department of Medical Oncology, Izmir, Turkey

${ }^{3}$ Dokuz Eylül University Hospital, Department of Medical Oncology, İzmir, Turkey

Figen ŞENGÜN INAN

Neslihan PARTLAK GÜNÜŞEN

Murat KESER

İlhan ÖZTOP

Correspondence: Figen Şengün İnan Dokuz Eylül University Faculty of Nursing, Department of Psychiatric Nursing, İzmir, Turkey Phone: +902324124793

E-mail: figensengun@gmail.com

\section{ABSTRACT}

Purpose: The aim of this study was to explore lived experiences of partners of breast cancer survivors.

Methods: A descriptive phenomenological study approach was used. Participants were purposively sampled from a university hospital in Turkey. Semi-structured individual interviews were conducted with 12 partners. The data were analysed using Colaizzi's data analysis method in descriptive phenomenological research.

Results: Three themes were identified from the data. These themes are difficulties, re-adaptation to life and new perspectives in relationship and life. The difficulties theme consisted of two sub-themes as difficulties about the posttreatment care of the survivor and individual difficulties. Re-adaptation to life theme was related to two sub theme as prioritizing the wife's needs, changes in responsibilities. The new perspectives in relationship and life theme consisted of sub themes of strengthening in relationship with wives, a new perspective on life.

Conclusion: Healthcare professionals should investigate the stressors and psychosocial well-being of the partners in follow-ups. In addition, partners should be supported with psychoeducational programs for understanding women's changes, post-treatment symptom management, emotional expression and open communication.

Keywords: Partners, breast cancer, post-treatment, qualitative design.

Meme Kanseri Tedavisini Tamamlamış Kadınların Eşlerinin Yaşam Deneyimleri: Psikososyal Güçlükler ve Değişimler

ÖZET

Amaç: Bu çalışmanın amacı meme kanseri tedavisini tamamlamış kadınların eşlerinin yaşam deneyimlerinin belirlenmesidir.

Yöntem: Çalışmada tanımlayıı fenomenoloji yaklaşımı kullanıımıştır. Katılımcılar Türkiye'de bir üniversite hastanesinden amaçlı örnekleme yöntemi ile belirlenmiştir. Yarı yapılandırılmış bireysel görüşmeler 12 eşle yürütülmüştür. Veri analizinde Colaizzi'nin tanımlayııı fenomenoloji araştırmalara yönelik veri analiz yöntemi kullanıımışır.

Bulgular: Çalışmada güçlükler, yaşama yeniden adaptasyon ve ilişkilerde ve yaşamda yeni bakış açıları olmak üzere üç tema belirlenmiştir. Güçükler teması: eşin tedavi sonrası bakımına yöenlik güçlükler ve bireysel güçlükler olarak ilki alt temadan oluşmaktadır. Yaşama yeniden adaptasyon teması: eşin gereksinimlerine öncelik verme ve sorumluluklarda değişim alt temalarını içermektedir. İlişkilerde ve yaşamda yeni bakış açıları teması eşle ilişkinin güçlenmesi ve yaşamda yeni bakış açıları alt temalarından oluşmaktadır.

Sonuç: Sağlık profesyonelleri tedavi sonrası dönem izlemlerinde eşlerin stresörlerini ve psikososyal iyi oluşluklarını değerlendirmelidirler. Ayrıca, eşler, tedavi sonrası semptom yönetimi, kadının deneyimlediği değişimler, duygu ifadesi ve açık iletişim konularında psikoeğitim programlarılla desteklenmelidir.

Anahtar Kelimeler: Eşler, meme kanseri, tedavi sonrası dönem, kalitatif araştırma.
Received
: 19 May 2021
Accepted
: 23 September 2021 
$\mathbf{T}$ oday, more people in the society maintain their lives as breast cancer survivors. In 2019, it is estimated that five-year relative survival rates of almost $91 \%$ after initial diagnosis (1). Similarly, the five-year overall survival rate is $86 \%$ in Turkey (2). However, breast cancer is a stressor affecting the psychological adaptation and well-being of both the survivors and their partners (3). In the post-treatment period, breast survivors face the longterm effects of the treatment, psychological distress and various difficulties related to social life (4-6). The survivors' support needs are mostly fulfilled by their partners and this support is important for the survivor's adjustment to life after treatment (7-9). Similarly, the interdependence of psychological distress in breast cancer survivors and their partners has been emphasized (10). However, data on partners' experiences are based on breast cancer survivors' perspectives or on the results of studies focusing on experiences of couples. This study aimed to provide a comprehensive understanding related to experiences in post-treatment period by gathering data directly from partners.

Partners are a significant source of support during both the treatment and recovery from breast cancer (9). Similarly, breast cancer survivors state that support of their partners is a crucial source for coping with the posttreatment stressors (11). Furthermore, studies point at fewer depressive symptoms in the breast cancer survivors who perceive greater empathy and emotional support from their partners $(9,12)$. However, it is revealed in some studies that partners might fail in providing this support and exhibit avoidance behaviours $(13,14)$. The studies focusing on the partners' experiences in the post-treatment period are limited. Studies in the treatment process show that spouses have difficulty in understanding their wives' emotions and helping them in symptom management, and have uncertainty about how they should support them $(15,16)$. Similarly, it was determined in a qualitative study in Turkey that women and their spouses experienced biopsychosocial difficulties and positive changes during from diagnosis to completion of treatment (17). In a follow-up study, husbands' domestic role strains and breast cancer-related concerns were determined to continue during and after the breast cancer treatment (18). In a qualitative study conducted with a dyadic approach, the changes experienced by the survivors and their partners in their roles, responsibilities and relationships during early post-treatment period were determined. Moreover, couples expressed their concerns about communication, intimacy and sexuality (7). In an another study in which spouses' support strategies for patients were explained, husbands stated that they maintained their family caregiver role even after treatment, focused on their wives' needs and helped them to adapt to family and social life (19). The male partners can feel excluded by the female partner after breast cancer surgery, and experience difficulties related to caregiving and providing emotional support to partner, financial and work related difficulties, worries about the effects of the cancer on their children, fear of cancer recurrence and anxiety (20). Similarly, in the study, male partners stated that emotional difficulties, changes in responsibilities the household chores and work life, worries about caring to children, and changes in relationship with their partner as impact of breast cancer (21). A systematic review study showed that the male spouses experienced negative changes in the area of emotional, financial and family life in the breast cancer treatment period (22). Besides drawing attention to the difficulties undergone by the partners, it is also stated that partners experienced positive changes such as the strengthening of the relationship, spiritual development and personal growth after breast cancer (16, 19, 20, 21, 22).

To sum up, the studies focusing on the partners' experiences in the post-treatment period are limited. In the present study, the focus was on the partners' experiences in the post-treatment period. More specifically, the aim of this study was to explore the partners' post-treatment psychosocial difficulties and their perceptions of changes in their lives. The results of the study are expected to provide guidance for healthcare professionals who will carry out the planning of interventions such as psychoeducation and counselling aimed at developing the psychosocial well-being of the partners of breast cancer survivors.

\section{Material and Methods}

Design

A descriptive phenomenological study approach was adopted. The reason for using descriptive phenomenology was to better understand the fundamental structure of each partner's lived experience (23).

\section{Participants}

This research was conducted with male partners of the breast cancer survivors followed by the medical oncology outpatient clinic of a university hospital in Turkey. Purposeful sampling method that aims to achieve maximum variation in participants' socio-demographic characteristics was used. Participants were eligible if they were over 18 years of age, and a partner of a breast cancer survivor whose initial hospital-based treatment had been 
completed at least six months, maximum five years prior to the study commencement. The study sample consisted of 12 marital partners of breast cancer survivors.

\section{Data collection}

Data were collected between February 2016 and January 2017 with semi-structured interviews. In the study, we used a personal information form and semi-structured interview guide. The personal information form included questions on sociodemographic characteristics such as age, educational status, and time since treatment completed. The semi-structured interview guide that consisted of open-end questions was prepared by the researchers in line with the relevant literature. Interview questions are given in Table 1.

Table 1. Semi-structured interview questions.

How did your life change after breast cancer?

What are your breast cancer-related difficulties?

How do you feel emotionally?

How do you evaluate your current social life?

How do you evaluate your relationship with your wife?

Firstly, the physicians assessed the characteristics of the breast cancer survivor in terms of sampling criteria during the follow-ups and explained the purpose of the study to the survivors and their partners who met the inclusion criteria. Then, interested partners were contacted by phone and interviews were scheduled by interviewer. Interviews were conducted by the first author who was experienced in studying with breast cancer survivors and had knowledge and experience in qualitative researches. Interviews were held face to face and one to one in the researcher's office. The mean duration of the interviews was 24 minutes. Field notes were taken during the interview. Interviews continued until reaching the saturation point. Data saturation was achieved at the $10^{\text {th }}$ interview.

\section{Data analysis}

The data were analysed using Colaizzi's data analysis method in descriptive phenomenological study. Firstly, each audiotape was repeatedly listened, and each transcript was read several times in order to obtain a general sense about the whole content. Next, significant statements and phrases that related to the investigated phenomenon were extracted from the transcripts and highlighted on each transcript pages. After this stage, the researchers reached a consensus. Then, meanings are formulated for each significant statement, and the formulated meanings were organised into clusters of themes. Each cluster was named with words unique to the content. The researchers re-examined and incorporated all the theme clusters, emergent themes and formulated meanings into an exhaustive description of the investigated phenomenon. Then the fundamental structure of the phenomenon was defined by discussion by the researchers. As a result, three themes revealing the experiences of partners were determined. Finally, the fundamental structure of the phenomenon was returned to available participants. Participants approved the findings be a reflection of their experiences (24).

\section{Trustworthiness}

The Consolidated criteria for reporting qualitative research (COREQ) was used to report this research (25). Trustworthiness of this study was achieved by adopting the criteria of credibility, transferability, confirmability, and dependability defined by Lincoln and Guba (26). To ensure the credibility of the study, at the beginning of the interviews, the participants were explained that they could express their opinions and emotions freely. After the interviews, the researcher made a summary of obtained data for participant checking. The researcher focused on participants' lived experience by maintaining her selfawareness in the interview and analysis process. To ensure the transferability of the study, purposive sampling method was used. A variety was obtained in terms of the parameters like age, and duration of ending the treatment in order to increase the data variety. Additionally, the study methods are detailed described. To ensure consistency of the study, all the interviews were conducted by the first researcher and she used the same interview guide and voice recorder during all interviews. Data were analysed independently by first two authors. The researcher who participated in the data collection and analysis attended courses for qualitative research methods. For depentability, the expert opinion was obtained for semi-structured interview guide (26).

\section{Ethical consideration}

This study was approved by the Ethics Committee of the university (decision no. 2016/02-02). Participants were informed about the aim of study and written consent was obtained before interview. 


\section{Results}

\section{Participants Characteristics}

Participants' average age was 51 years. Of the participants, five were university graduates, and six were unemployed. Participants reported that their wives had completed their hospital-based treatment of 21 months on average, prior to participation in the study (Table 2 ).

\begin{tabular}{|c|c|c|c|c|c|}
\hline Participant & $\begin{array}{l}\text { Age, } \\
\text { Years }\end{array}$ & Education & Employed & $\begin{array}{l}\text { Marital } \\
\text { years }\end{array}$ & $\begin{array}{c}\text { Time since } \\
\text { treatment } \\
\text { completed } \\
\text { (months) }\end{array}$ \\
\hline P1 & 65 & $\begin{array}{c}\text { Primary } \\
\text { School }\end{array}$ & $\begin{array}{c}\text { Not } \\
\text { Employed }\end{array}$ & 32 & 9 \\
\hline P2 & 59 & $\begin{array}{c}\text { Primary } \\
\text { School }\end{array}$ & $\begin{array}{c}\text { Not } \\
\text { Employed }\end{array}$ & 25 & 38 \\
\hline P3 & 40 & University & $\begin{array}{c}\text { Not } \\
\text { Employed }\end{array}$ & 10 & 32 \\
\hline P4 & 62 & $\begin{array}{c}\text { Primary } \\
\text { School }\end{array}$ & $\begin{array}{c}\text { Not } \\
\text { Employed }\end{array}$ & 42 & 18 \\
\hline P5 & 32 & $\begin{array}{l}\text { High } \\
\text { School }\end{array}$ & Employed & 6 & 10 \\
\hline P6 & 42 & University & Employed & 9 & 16 \\
\hline P7 & 67 & $\begin{array}{l}\text { High } \\
\text { School }\end{array}$ & $\begin{array}{c}\text { Not } \\
\text { Employed }\end{array}$ & 23 & 24 \\
\hline P8 & 55 & University & Employed & 24 & 14 \\
\hline P9 & 60 & University & $\begin{array}{c}\text { Not } \\
\text { Employed }\end{array}$ & 37 & 4 \\
\hline P10 & 41 & $\begin{array}{l}\text { High } \\
\text { School }\end{array}$ & Employed & 17 & 40 \\
\hline P11 & 36 & University & Employed & 5 & 21 \\
\hline P12 & 53 & $\begin{array}{c}\text { Primary } \\
\text { School }\end{array}$ & Employed & 29 & 33 \\
\hline
\end{tabular}

Results were classified as three themes. These themes are difficulties, re-adaptation to life and new perspectives in life and relationship (Table 3 ).
Theme 1: Difficulties

The difficulties theme consisted of two sub-themes as difficulties about the post-treatment care of the survivor and individual difficulties.

\section{Sub-theme 1: Difficulties about the post-treatment} care of the survivor. Partners were aware of the negative effects of some symptoms, which continued after breast cancer, on the lives of the wives. At this point, they were eager to support their wives, but they pointed at difficulties in providing support. "Let's say her arm got swollen. I tell her not to worry about it, but she doesn't listen to me.... I try to stop her." (P2) Some of the partners said that their sexual lives were affected negatively due to wives' lack of interest in sex after cancer and the problems with body image, and they could not talk about these issues openly. "We never talked about sexuality between us. When she doesn't want it, I don't force her. But she has been quite distant within the last one or two years, because she worries about this thing a lot." (P7)

Another issue which partners find difficult to manage is the emotional changes in the wives. They stated the feelings, which they found difficult to manage as sensitivity, unhappiness, anger and fear of recurrence. "When we go there every 3 months, she keeps saying that something will come up, so she is always stressed and nervous. "She has the issue of 'will this be over?"' (P9)

The partners stated that they tried to support their wives' re-integration to social life. On the other hand, community's negative attitudes towards cancer and recovery from cancer were a challenge affecting their wives' social involvement. "For instance, some talk ironically. They say, 'You look fine, you are fine, right?' There was someone who had the same, it kept spreading, it never comes to an end..." (P4)

\begin{tabular}{|l|l|}
\hline \multicolumn{2}{|l|}{ Table 3. Themes and subthemes. } \\
\hline Themes & Subthemes \\
\hline \multirow{2}{*}{ Difficulties } & Difficulties about the post-treatment care of the survivor \\
\cline { 2 - 3 } & Individual difficulties \\
\hline \multirow{2}{*}{ Re-adaptation to life } & Prioritizing the wife's needs \\
\cline { 2 - 3 } & Changes in responsibilities \\
\hline \multirow{2}{*}{ New perspectives in life and relationship } & Strengthening in relationship with wives \\
\cline { 2 - 2 } & A new perspective on life \\
\hline
\end{tabular}


Sub-theme 2: Individual difficulties. There are also individual difficulties explained by the partners directly about themselves. Experiencing sadness due to remembering the treatment process and having the fear of recurrence were among the emotional challenges affecting the partners' life. Although they were happy that the treatment was over, they were worried about whether they would return to normal life and whether recovery from cancer would be permanent. "I sometimes tell myself'I hope it never happens again.' These doubts are always there..." (P8). Another emotional challenge mentioned by some partners was that they blamed themselves for the emergence of their wives' illness. "I think about whether I made mistakes or made her sad in a way that she came to this point... Asking to myself..." (P4)

The partners stated that they had difficulty in coping with these difficult feelings. They thought they should be a source of morale for their wives. They also stated that they refrained from sharing their feelings with their wives because thought that this might increase their wives' distress level. "There is a heavy responsibility. All the burden is on me. But I have to be a source of morale!" (P5)

The partners were eager to restart social activities they used to do before cancer. However, they stated that they were neither able to achieve this balance in their lives nor to allocate time for themselves to socialize and feel good. "When I want to distract myself a little bit and turn the computer on, she tells me not to deal with that tin can, but with her. I sometimes feel bored and fed up. I don't go anywhere on my own" (P6). In addition, the social networks of the partners also decreased. They kept a distance with their acquaintances who did not support them disease period. "She paid attention to who called and asked about her, and who didn't, she got offended or didn't want to see them. She doesn't want them now. And I only say hello to them." (P12)

\section{Theme 2: Re-adaptation to life}

The partners tried to adapt to the new situation after breast cancer treatment. They expressed that they prioritized their wives' needs, performed domestic roles and assumed responsibility in post-treatment follow-ups and treatments.

Sub-theme 1: Prioritizing the wife's needs. The partners were aware of the challenging process their wives undergo and the physical and emotional effects of this process. They stated that they supported their wives in the recovery process by putting their wives in the centre of their lives and adjusting their lives according to their wives' needs. "Mostly, I look for things, which will make my wife happy. I help my wife in every sense so that she doesn't get sad. When I'm buying something, I am trying to buy it for her." (P7). Partners also try to protect their wives against both physical and emotional difficulties. "We have to be a bit more protective after the disease. Both materially and morally. I mean she shouldn't do physical work; we shouldn't let her do it." (P1)

Sub-theme 2: Changes in responsibilities. The partners stated that their domestic responsibilities changed during the treatment process. However, in the post-treatment period, they expected their wives to continue their domestic roles as they used to do before cancer. However, they stated that they tried to compensate their wives' roles in performing domestic responsibilities, and that they continued to take these responsibilities when necessary. "After she got the disease, I helped her with household chores more often. Now I clean the house, but I'm trying to get her back to those old days." (P4)

In addition, partners try to support the medical follow-up and treatments of their wives. They don't leave their wives alone while going to the follow-up and consider it as their responsibility. "You adjust all of your schedules; you adjust all of your life according to her. You take all the situations into account: She has an appointment on that day, what will happen if the results are bad?" (P10)

\section{Theme 3: New perspectives in relationship and life}

Although breast cancer is a difficult process for partners, they said that struggling with it helped them adopt a positive perspective on life, and their relationships with their wives got stronger.

\section{Sub-theme 1: Strengthening in relationship with wi-}

ves. The partners stated that their relationship with their wives deepened and strengthened. In the cancer trajectory, there was an increase in the sharing and commitment among the spouses. The partners thought that they valued their wives more, and that their wives were worth every sacrifice. "I feel more attached, because we shared a lot, unbelievable things during the cancer as well. The more sacrifice and effort I make the bigger value it gains." (P8) 
Sub-theme 2: A new perspective on life. This challenging process experienced by the partners also led to some positive changes in their view of life. The partners stated that they understood the value of life after cancer and their priorities changed. "Living well and living by making others happy is what is important in life, this is my perspective on life now..." (P11)

\section{Discussion}

In this study, partners expressed that they had difficulty in managing post-treatment symptoms and providing emotional support for the wives. In additionally, partners have difficulties maintaining their emotional well-being because of caregiving. Likewise, attention is drawn to the individual and mutual difficulties of the partners in the literature $(6,7,20,22,27)$. In this study, similarly to the literature, body image and sexual matters were defined as a taboo, which couldn't be shared with the partners and the health professionals (6). In Turkish culture, it can be difficult for partners to share their emotions in private matters such as body image and sexuality. However, attention is attracted in a study to the protective role of the empathy perceived by the woman from the partner in her depression related to the problems of body image (12). At this point, it is necessary for the health professionals to do identification in respect of body image and sexuality in both survivors and their partners and to provide support for open communication in survivorship care. Furthermore, another difficulty defined by the partners was the stigmatization of the community about cancer. Partners stated both the effect of the stigmatization on the survivors and the decrease in their social supports due to stigmatization as a difficulty. In Turkey, cancer is a stigmatized disease and mostly refers to the terms of pain, suffering and death in the community. Similarly, breast cancer survivors explained the stigmatization as a stressor (11). At this point, health professionals must be aware of the effects of stigmatization about cancer on both the survivors and the partners during the follow-ups.

Partners talked about the individual difficulties caused by caregiving as well. Similarly, partners had difficulties in managing their own health and well-being $(20,22$, 28). In the literature, attention is drawn to the burden of caregiving experienced by the husbands, and the caregiver burden is stated as the predictor of the psychological distress among husbands after breast cancer (18). In Turkish culture, family members are primarily responsible for the care of the patient. The best possible care is aimed for the patient. At this point, the suffering of the survivor from the permanent symptoms and emotional problems may cause the partners to feel incompetent in caregiving and to have negative feelings. In addition, partners both have difficulty in managing the survivor's fear of recurrence and try to cope with this fear on his own. Fear of recurrence is a dyadic difficulty $(20,29)$. For feeling guilty, it is important to explain the perceptions of the partners about the causes of cancer and to provide them with the appropriate consultancy.

Partners cannot fulfill their own needs for psychosocial well-being. The barriers were not prioritizing own needs, not being able to share feelings with wives and decrease in their social networks during cancer. Similarly, it is reported in studies that partners put the needs of their wives in the centre of their lives and concentrate on their sick spouse/partner' health and well-being $(7,19,30)$. Partners should be supported with psychoeducational interventions for maintaining their social relationships, sharing their feelings with their wives and developing effective coping strategies.

Partners who have undertaken the caregiver role in the treatment process would probably undertake a new role and identity in the survivorship period. However, the posttreatment period is related to uncertainties and complexities, including those relating to personal and social identities for the partners (31). In this study, partners described a restructuring process. They assisted the survivors during the post-treatment medication and follow-ups and attended to household tasks that survivor can barely do. These findings are similar to the literature (18). Symptoms such as lymphedema, tiredness, pain and movement restriction that continue after the treatment affect the women's performance of domestic roles. At this point, the support provided by the family members is important (11). However, exhibition of an excessively protective approach in providing support may affect the recovery process of the survivor negatively. Health professionals' investigation of the domestic roles, quality of the roles and tasks and the partners' approach to them is important.

Partners said that they adopted a positive perspective on life, and their relationships with their wives got stronger after breast cancer. After life-threatening diseases such as cancer, not only patients but also their partners experience positive changes $(16,19,22,32)$. In a review, spousal caregivers for cancer patients experienced enhanced relationship with the care-receiver, and the feeling of being rewarded, and a sense of personal growth were defined 
(33). The another positive changes were described for partners as follows: a deepening sense of closeness with their wives, spiritual development, couple growth, and improved relationships with others (20). Here, the important point is the approach of healthcare professionals to these positive changes, which partners went through following the cancer struggle, as a source for coping with post-treatment difficulties.

\section{Limitations}

This qualitative study provides a deeper understanding of the experience of partners of breast cancer survivors. In addition, this is the first study to explore experiences of Turkish male partners in the breast cancer post-treatment period. However, there are some limitations of the study. Firstly, all participants were recruited from a large city and a single center in Turkey. In addition, volunteer partners who came to policlinic follow-ups with the survivors were included in this study.

\section{Conclusion}

The results of the study showed that partners experience psychosocial difficulties but also perceive growth after breast cancer. Moreover, partners focus more on meeting the survivors' needs, have difficulty in expressing their own emotional needs and disregard their own well-being. Partners' focus on the needs of their wives and inability to express their own needs may cause the health professionals not to understand the needs of this group and underestimate these needs. As a dimension of the survivorship care, psychosocial well-being of the partners should be investigated in the follow-ups and partners must be provided with coping support. Healthcare professionals can encourage affected partners to disclosure difficult feelings. Health professionals must be aware of the effects of stigmatization about cancer on both the survivors and the partners during the follow-ups. In addition, partners should be supported with psychoeducational programs for understanding women's changes, survivorship symptom management, providing emotional support, emotional expression, open communication, and developing effective coping strategies. Lastly, healthcare professionals should use the positive changes, which partners went through following the cancer struggle, as a source for coping with post-treatment difficulties.

It is recommended that qualitative studies be conducted in the future should focus on the quality of the relationship between survivors and partners, or on the coping characteristics of partners.

\section{References}

1. American Cancer Society, 2019. Breast Cancer Facts \& Figures 20192020. Atlanta: American Cancer Society, Inc. 2019. Available online: https://www.cancer.org/content/dam/cancer-org/research/cancerfacts-and-statistics/breast-cancer-facts-and-figures/breast-cancerfacts-and-figures-2019-2020.pdf. [Accessed 10 th March , 2020].

2. Özmen V, Özmen T and Doğru V. Breast cancer in Turkey; An analysis of 20.000 patients with breast cancer. Eur J Breast Health. 2019;15(3):141-6. DOI:10.5152/ejbh.2019.4890.

3. Lillie HM, Venetis MK and Chernichky-Karcher SM. "He would never let me just give up": Communicatively constructing dyadic resilience in the experience of breast cancer. HealthCommun.2018;33(12):1516-24. DOI:10.1080/10410236.2017 .1372049.

4. Şengün İnan F and Üstün B. Biopsychosocial changes in posttreatment period of breast cancer. Eur J Breast Health. 2013;9:48-51. DOI:10.5152/tjbh.2013.03.

5. Ploos van Amstel FK, van den Berg SW, van Laarhoven HW, et al. Distress screening remains important during follow-up after primary breast cancer treatment. Support Care Cancer. 2013;21(8): 2107-15. DOI:10.1007/s00520-013-1764-0.

6. Jakobsen K, Magnus E, Lundgren S, et al. Everyday life in breast cancer survivors experiencing challenges: A qualitative study. Scand J Occup Ther. 2018;25(4):298-307. DOI:10.1080/11038128.2017.1335 777.

7. Keesing S, Rosenwax $L$ and McNamara B. A dyadic approach to understanding the impact of breast cancer on relationships between partners during early survivorship. BMC Womens Health. 2016;16(1):1-14. DOI:10.1186/s12905-016-0337-z.

8. Kinsinger SW, Laurenceau JP, Carver CS, et al. Perceived partner support and psychosexual adjustment to breast cancer. Psychol Health. 2011;26(12):1571-88. DOI:10.1080/08870446.2010.533771.

9. Talley A, Molix L, Schlegel RJ, et al. The influence of breast cancer survivors' perceived partner social support and need satisfaction on depressive symptoms: a longitudinal analysis. Psychol Health. 2010;25(4):433-49. DOI:10.1080/08870440802582682.

10. Segrin $C$ and Badger TA. Psychological and physical distress are interdependent in breast cancer survivors and their partners. Psychol Health Med. 2014;19(6):716-23. DOI:10.1080/13548506.201 3.871304.

11. Şengün İnan F and Üstün B. Experiences of Turkish survivors of breast cancer: Neuman Systems Model Perspective. Jpn J Nurs Sci. 2016;13:466-77. DOI:10.1111/jjns.12129.

12. Fang SY, Chang HT and Shu BC. The moderating effect of perceived partner empathy on body image and depression among breast cancer survivors. Psychooncology. 2015;24(12):1815-22. DOI:10.1002/pon.3868.

13. Lim JW, Paek MS and Shon EJ. Gender and role differences in couples communication during cancer survivorship. Cancer Nurs. 2015;38(3):E51-60. DOI:10.1097/NCC.0000000000000191.

14. Yamamoto $\mathrm{S}$, Tazumi $\mathrm{K}$ and Arao $\mathrm{H}$. Support not corresponding to transition to a new treatment: Women's perceptions of support provided by their male partners during hormonal therapy. Int J Qual Stud Health Well-being. 2015;10(1):292-83. DOI:10.3402/qhw. v10.29283.

15. Chung $C$ and Hwang E. Couples' experiences of breast cancer in Korea: A descriptive qualitative study. Cancer Nurs. 2012;35(3):21120. DOI:10.1097/NCC.0b013e31822a60db

16. Gursoy A, Kocan S and Aktug C. Nothing is more important than my partner's health:Turkish men's perspectives on partner's appearance after mastectomy and alopecia. Eur J Oncol Nurs. 2017;29:23-30. DOI:10.1016/j.ejon.2017.04.006. 
17. Çömez $S$ and Karayurt Ö. We as spouses have experienced a real disaster!: a qualitative study of women with breast cancer and their spouses. Cancer Nurs. 2016;39(5):E19-28. DOI:10.1097/ NCC.0000000000000306.

18. Wagner CD, Das LT, Bigatti SM, et al. Characterizing burden, caregiving benefits, and psychological distress of husbands of breast cancer patients during treatment and beyond. Cancer Nurs. 2011;34(4):E21-30. DOI:10.1097/NCC.0b013e31820251f5.

19. Gao L, Liu JE, Zhou XP, et al. Supporting her as the situation changes: A qualitative study of spousal support strategies for patients with breast cancer in China. Eur J Cancer Care. 2020;29(1):e13176. DOI:10.1111/ecc.13176.

20. Catania AM, Sammut Scerri C, and Catania GJ. Men's experience of their partners' breast cancer diagnosis, breast surgery and oncological treatment. J Clin Nurs. 2019;28(9-10):1899-1910. DOI: 10.1111/jocn.14800.

21. Fitch MI and Allard M. Perspectives of husbands of women with breast cancer: impact and response. Can Oncol Nurs J. 2007;17(2):6678. DOI: $10.5737 / 1181912 \times 1726671$.

22. Lopes VB, Lobo APA, Da Silva Junior GB, et al. The experience of male spouses in the context of breast cancer: a systematic review of the literature. Psychol Health Med. 2018;23(1):89-98. DOI: 10.1080/13548506.2017.1332374.

23. Lopez KA and Willis DG. Descriptive versus interpretive phenomenology: Their contributions to nursing knowledge. Qual Health Res. 2004;14(5):726-35. DOI:10.1177/1049732304263638.

24. Morrow R, Rodriguez A and King N. Colaizzi's descriptive phenomenological method. The Psychologist. 2015;28(8):643-44.

25. Tong A, Sainsbury P and Craig J. Consolidated criteria for reporting qualitative research (COREQ): a 32- item checklist for interviews and focus group. Int J Qual Health Care. 2007;19(6):349-57. DOI:10.1093/ intqhc/mzm042.

26. Lincoln SY and Guba GE. Naturalistic inquiry. Beverly Hills, CA: Sage. 1985.

27. Pauwels E, De Bourdeaudhuij I, Charlier C, et al. Psychosocial characteristics associated with breast cancer survivors' intimate partners' needs for information and support after primary breast cancer treatment. J Psychosoc Oncol. 2012;30(1):1-20. DOI:10.1080 /07347332.2011.633982.

28. Adams $E$, Boulton $M$, Rose PW, et al. A qualitative study exploring the experience of the partners of cancer survivors and their views on the role of primary care. Support Care Cancer. 2012;20(11):2785-94. DOI:10.1007/s00520-012-1400-4.

29. Janz NK, LiY, Beesley LJ, et al. Worry about recurrence in a multi-ethnic population of breast cancer survivors and their partners. Support Care Cancer. 2016;24(11):4669-78. DOI:10.1007/s00520-016-3314-z.

30. Dorros SM, Segrin C, and Badger TA. Cancer survivors' and partners' key concerns and quality of life. Psychol Health. 2017;32(11):140727. DOI:10.1080/08870446.2017.

31. Miller LE and Caughlin JP. "We're going to be survivors": couples' identity challenges during and after cancer treatment. Communication Monographs. 2013;80(1):63-82. DOI:10.1080/0363 7751.2012.739703.

32. Arnedo CO and Casellas-Grau A. Vicarious or secondary posttraumatic growth: how are positive changes transmitted to significant others after experiencing a traumatic event? In: Martin C, Preedy V and Patel V. (eds), Comprehensive Guide to Post-Traumatic Stress Disorders. Springer, Cham. 2016;1762-82. DOI:10.1007/978-3-319-08359-9_76.

33. Li $\mathrm{Q}$ and Loke AY. The positive aspects of caregiving for cancer patients: a critical review of the literature and directions for future research. Psychooncology. 2013;22(11):2399-407. DOI:10.1002/ pon.3311. 